УДК 811.111'366.58:316.48

DOI: $10.24144 / 2617-3921.2020 .18 .91-100$

Oksana Myhalets

Candidate of Philological Sciences, Associate Professor of English Philology Department

Uzhhorod National University orcid.org/0000-0003-0594-3158

Uzhhorod, Ukraine, +38(050) 9174002

myhalets.oksana@gmail.com

\title{
Semantics of the verbs with the middle degree of polysemy denoting conflict actions in modern English
}

Анотація. Лінгвісти усього світу дотримуються думки, що в даний час лексична семантика є найбільи продуктивною основою для всебічного вивчення мовного змісту, без якого визначена мовна система не може бути адекватно представлена в иілому. Семантика визначається як вивчення слів та їхніх значень. Зростаючий інтерес до вивчення мовних одиниць у семантично об'єднаній групі можна пояснити тим, що лише ретельно зібраний та систематизований мовний матеріал дає можливість вирішити цілий спектр найбільш значущих питань. Саме тому ия стаття присвячена дослідженню групи дієслів із середнім ступенем полісемії на позначення конфліктних дій, які займають важливе місие в системі англійської мови. Конфліктні дії класифікуються за видами та формами вираження, але найбільш чітко їхня багатогранність виявлясться за допомогою формалізованого дослідження. На основі методики формалізованого аналізу лексичної семантики виявлено їхні кількісні та якісні характеристики. Крім того, розкрито як спільні, так $і$ відмінні риси семантики мовних одиниць у досліджуваній мові. На иій основі висвітлено лексичну семантику дієслів на позначення конфліктних дій та їхній семний склад в сучасній англійській мові. Семантичний аналіз дієслів із середнім ступенем полісемї на позначення конфліктних дій в сучасній англійській мові дає підставу розглядати досліджуваний фрагмент лексики як певну семантичну структуру, елементи якої розташовані ісрархічно в їхніх різноманітних відношеннях як між собою, так $i$ з іншими словами. У свою чергу, конфліктні діï, щзо базуються на протилежних иілях, інтересах, типах поведінки людей та соціальних груп, щяо супроводжуються негативними психологічними проявами, є привабливим об'єктом психологічного, сочіологічного та лінгвістичного аналізу. Крім того, не секрет, щуо конфліктні діï - ие постійні «супутники» людини, щуо супроводжують ї̈ з першого до останнього дня життя. Життя включає «вічні» проблеми між керівником $і$ підлеглими, спільне проживання людей різних характерів, інтересів та поглядів на життя. Таким чином, на иьому 
рівні виникають конфліктні дї, щуо зіштовхують нас з такими явищами, як терор, страйк, війна, суперечка тощо.

Ключові слова: лексична семантика, конфліктні дї̈, формалізований аналіз, семний склад, якісні та кількісні характеристики.

Abstract. Linguists around the world hold the opinion that nowadays lexical semantics is the most productive basis for all-round studying linguistic content without which the definite language system can't be adequately presented in general. Semantics is defined as the study of words and their meanings. The growing interest to the study of the language units in the semantically united group can be explained by the fact that only carefully collected and classified language material allows to solve a range of the most important issues.

That is why the present article deals with the study of the group of verbs with the middle degree of polysemy denoting conflict actions which occupy a significant place in the system of the English language. Conflict actions are classified by types and forms of expression, but most clearly their versatility is revealed through their formalized research. By means of the formalized lexical semantics' analysis methodology their qualitative and quantitative characteristics have been disclosed. Besides, both common and distinctive features of the units' semantics under study have been revealed. On this basis lexical semantics of the verbs denoting conflict actions as well as their seme stock in modern English have been highlighted. The semantic analysis of the verbs with the middle degree of polysemy denoting conflict actions in modern English gives reason to consider the lexis fragment under study as a definite semantic structure, the elements of which are placed hierarchically in their various relationships with both each other and other words. In its turn, the conflict actions based on the opposing goals, interests, types of people's behavior and social groups, accompanied by negative psychological manifestations, are worth studying from psychological, sociological and linguistic aspects. In addition, it is no secret that conflict actions are constant "fellows" of man which accompany a person from the first until the last day of life. Life comprises "everlasting" problems between leader and subordinates, common habitation of people of various characters, interests and views on life. Thus, at this level conflict actions arise that confront us with such phenomena as terror, strike, war, controversy etc. In the process of our complex lexico-semantic analysis, we have found common (to make (smth.) against smb.; to contend in, for, with or against smth./smb.; violently; side by side with; to oppose (in smth.); rebelliously; to oppose by contrary operations; to fight for, against; to meet in combat; to engage in battle; to strike; to put an end to; to strive in, with or against smb. or smth.; to throw, to combat, etc.) and distinctive (to break up with smb.; to expose; to urge, to close, to repulse by force of arms; to follow a person or thing; to comply with, to continue; to load or burden with smth.; to tyrannize over, etc.) features of the lexical units in question.

Keywords: lexical semantics, conflict actions, formalized analysis, seme stock, qualitative and quantitative characteristics. 
Introduction. Language is treated as a system of communication, a medium for thought, a vehicle for literary expression, a social institution, a catalyst for nation building. All human beings speak at least one language and it is hard to imagine significant social, intellectual or artistic activity taking place in its absence [1, p. 11]. Language is the most significant way to preserve and form the human knowledge of the world. Representing the latter in the process of human activity, an individual fixes the results of his/her cognition in a word. Furthermore, language becomes distinctly human through its verbal and non-verbal dimensions [5, p. 12].

Given the fact that language is characterized by its special system of nomination for the creation of a dictionary, which simultaneously represents an inventory of the corresponding culture, we believe that the culture of the people is most clearly manifested in their vocabulary. Besides, an explanatory dictionary expresses the meaning, in other words something the culture is composed of.

Linguists who are interested in the meanings of words, and the relations between words' meanings, study lexical semantics. Thematic roles provide one very popular framework for investigating lexical semantics, in particular the lexical semantics of verbs, but not the only one. A significant number of scholars have recognized the importance of studying lexical semantics, especially when it concerns different languages in their comparison (O. I. Holubovska, M. P. Kocherhan, A. A. Luchyk, V. M. Manakin, M. P. Fabian, A. Cruse, A. Wierzbicka and many others). Lexical semantics belongs to less investigated issues of modern linguistics. There are hardly any research devoted to lexical semantic analysis of the verbs denoting conflict actions in modern English.

The purpose of the present article is to reveal the semantic peculiarities of the language units with the middle degree of polysemy in modern English. According to the purpose of our research, the following tasks have been put forward: a) to collect, classify and analyze the language units denoting conflict actions in modern English; b) to reveal their semantic peculiarities.

The relevance of the research is determined by the necessity of all-round study of the semantic peculiarities of the verbs denoting conflict actions in English, taking into account both their system-structural and semantic characteristics.

Material and methods. The research material of the present article includes English language units denoting conflict actions collected from Oxford English Dictionary in 20 volumes.

To choose the material of study - the words denoting conflict actions in modern English - we use formal, but exclusively linguistic criterion, i.e. referring it to one part of speech - the verbs. To study the relevant features of the verbs in question, the procedure of formalized lexical semantics' analysis has been used, further developed by professor M. P. Fabian [3; 4]. This method allows revealing the semantics of the verbs denoting conflict actions by studying the correlations between language units and their meanings, at the same time singling out their seme stock peculiarities. 
Results and Discussion. Due to the fact, that conflict actions are daily phenomena of social life, conflict vocabulary functions and develops in close connection with society.

In the development of a particular language, the social nature of language units denoting conflict actions appears in multiple variations. This fact requires differentiating the external factors of direct influence of the investigated class of verbs on the vocabulary from internal ones related to the mechanism of the lexical system formation. Correlation of these factors is qualified as the relation of necessity and opportunity.

The structure and system of any language is presented in dictionaries of different types. Their most comprehensive representation is given in explanatory dictionaries in which phonology, morphology, word formation etc. do not stand in autonomous relations, but act as a complex expression of the lexical units' content [3, p. 18].

Lexical practice alignes researches to study the word not as an isolated object, but as an organic element of the language system. The study of the text, as a result of speech activity, is used by lexicographers to determine the lexical meanings of words as speech facts. Any word in the explanatory dictionary combines form of expression and meaning. The form of the word is a multifaceted phenomenon, due to which the lexical meaning is complete. Furthermore, the explanatory dictionary allows analyzing language means of expressing conflict actions by linguistic methods. That is why the explanatory dictionary serves as the main source of language material in studying the system relations of the verbs denoting conflict actions and their places in the system of language. Interpretation of the words in the dictionary serves as a basis for describing their meanings in terms of semantic components.

The lexis denoting conflict actions in English is represented by 300 verbs, possessing 1715 lexical meanings. They are divided into 4 groups according to the degree of polysemy and their semantic characteristics: the language units with the highest (11), middle (61), low degree of polysemy (221) and monosemantic (7) words:

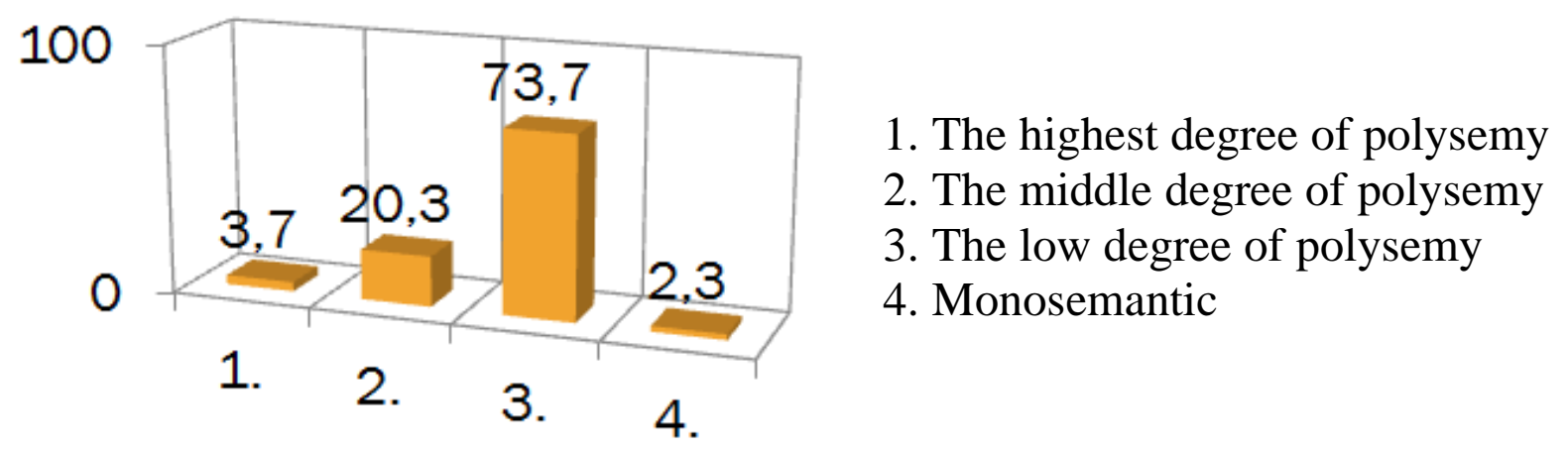

The present paper focuses on the lexico-semantic analysis of the 2nd group of verbs denoting conflict actions in English. The lexemes in question comprise a part of the English lexis - 19 verbs characterized by 39-30 meanings. They express the 
views on the real world characteristic of both an individual and the society he/she lives in.

The lexical units to oppose, to push, to sue, to oppress, to beat, to deal, to determine, to split, to wrestle, to clear, to judge, to divide, to much, to void, to cross, to top, to spill, to refuse, to prevent denote conflict actions and have both common and distinctive features.

The first one to oppose (39 meanings) has a broad semantics which explicitly denotes the conflict actions with their causes and consequences (to expose, to set smth. against or on the other side, to contrast, to place as an obstacle, to set or place (a person) as an antagonist, to set oneself in opposition, contend against, act in opposition or other resistance to, to be contrary to, to withstand, to combat, to stand in the way of, obstract, etc.).

Strengthening of the conflict actions, especially in wrestling or military operations between two or more countries or opposing groups within a country is found in the lexical meanings of the verb to push (37 meanings): to exert force upon or against, to drive or repulse by force of arms, to move, throw forward, or advance (a force) against opposition, to thrust with a pointed weapon, to stab with a weapon, to strike, to exert pressure upon smth., to make one's way with force or persistence (as against difficulty or opposition), to force a thing into more intense action. It can form phrases which have the following semantics: to move or cause (someone) to be moved roughly from place to place, to manhandle; to browbeat, bully, domineer over - to push (someone) around; to punch (someone) on the nose - to push (someone's) face in; to press forward, to advance with continued effort - to push on; to make one's way by thrusting obstacles or opponents aside - to push one's way; to cause (an action) to be rushed; to hurry, cut fine - to push it, push things; to press or carry by force to a conclusion - to push through.

To sue and to oppress have 36 meanings each, but they are qualitatively different. For example to sue, on the one hand, denotes the process of movement, search, implementation, following someone (to follow a person or thing in motion, to follow with the eyes, to come after, to succeed, to chase, to take as a guide, to comply with, to continue, to proceed, to seek after, to accompany), and, on the other hand, is linked with the jurisprudence: to prosecute, to file a complaint, to initiate a case (to institute legal proceedings against a person, to prosecute in a court of law, to bring a civil action against; to sue at law, to appeal to, to petition, to make application before a court for the grant of, to institute a suit for, make a legal claim to, to woo, court, to plead, appeal, supplicate). At the same time, the lexical unit to oppress means: to oppress, to depress, to upset, to subdue, to tyrannize, to commit violence, etc. (to press upon, to crush, to bear down in battle, to suppress, to put an end to, to load or burden with cruel or unjust impositions or restraints, to tyrannize over, to molest, to trouble, to harass, to distress, to force, to violate, to ravish, to urge, to close, to shut up, to fall upon, to keep out of sight).

Analyzing the semantics of verbs denoting conflict actions in modern English, we note that the meanings of polysemantic words differ not only in their structure 
and place in the system of English, but also in their status which is defined as a set of correlated non-meaningful traits determining the role of the studied word meanings in the system of language means of nomination [2, p. 63]. Each meaning interacts with other meanings acting as part of the general system of nominative language means, i.e. interacts with other meanings outside semantic structure of the word. Owing to this correlation, the language status of the word is revealed.

The verb to beat (35 meanings) establishes the relations with the lexical units to deal and to determine denoting not only conflict actions, disputes, misunderstandings, confrontations, but their disclosure, resolution and results: to beat (to strike with repeated blows, to exchange blows, to bombard, to dash against, impinge on, strike violently, assail, to overcome, to conquer in battle, to surpass, to force or impel by striking, to break, to smash, or overthrow by hard knocks, to batter); to deal (to engage with in conflict; to contend or fight about, to deliver blows, etc.; to have intercourse or dealings with, to associate with, to carry on negotiations, negotiate, treat with); to determine (to put an end to, to come to an end, to conclude, terminate, to cease to exist or be in force, to die, to expire, to set bounds to, to limit, to restrict to, to settle or decide a dispute, to fix, to conclude from reasoning, investigation, to ascertain definitely by observation, examination, calculation, to be defined as to position, to discuss and resolve a disputed question, to direct to some end or conclusion, to bring to the determination, decision or resolution (to do smth.), to resolve upon, to be finally and firmly resolved), etc.

In addition, the common feature of the lexemes to beat, to deal and to determine is their ability to be used in phrases and possess figurative meanings: to beat the air, beat the wind, (beat the water) - to fight to no purpose or against no opposition; to have (a person) beat - to be sure of his defeat; to beat up the quarters of - to arouse, disturb; beat in - to knock or force in by beating; beat off - to drive away from by blows, attacks, volleys; beat out - a. To knock or force or shape out by beating; b. To drive out by force or fighting; to beat a person at his (also her, etc.) own game - to defeat or outdo a person in his or her chosen activity or field of expertise, esp. by using his or her methods. To deal: to deal with - to act in regard to, administer, handle, dispose in any way of (a thing); to deal with - to act towards (any one), to treat (in some specified way); to deal on, upon - to set to work upon. To determine: to determine to do something - to decide to do something. Among the distinctive semantic features, we point out the following: for to deal - to divide, to distribute, to share, to separate, to bestow, give forth, render, deliver, to act, to proceed, to portion out, apportion, etc.; for to determine - to give a terminus or aim to, to give tendency or direction to, to direct, to decide the course of; to impel to (some destination), to be directed upon (anything), to be bound for etc.

The lexical units to split and to wrestle (34 meanings) as part of the English vocabulary denoting conflict actions are revealed through their individual meanings. To split means to break up, to separate or take apart, to divide or apportion to, to disclose, to let out, to reveal, to depart from, to leave, to part or break by striking, to fall out or disagree, to break or quarrel with a person, to become divorced, to 
run, to betray confidence, to give information detrimental to others. In its turn, to wrestle in sports means to strive with the competitor (to strive with strength and skill to throw a person to the ground by grappling with him, to endeavour to overpower and lay down another, esp. in a contest governed by fixed rules, by embracing his body and limbs and tripping or overbalancing him, to struggle physically), and figuratively - to wrestle with/against something e.g. temptation (to strive or labour against difficulties, forces, circumstances, personal feelings). In addition, the semantics of the verb to wrestle denotes the formulas of the interpretation indicating the conflict deployment - to engage in conflict or strife, to act against each other, to engage in argument, debate, or controversy, to debate, dispute, to contend or struggle in hostility or opposition (with or against another or others).

The verbs to clear and to judge (33 meanings), on the one hand, have the same quantitative characteristic, but, on the other hand, they represent different ways of resolving conflict actions, especially in order to keep relations at work, at home, and in the community: to clear - to become clear, to convince, to clarify, to explain, to elucidate, to make manifest, demonstrate, prove, to make pure, innocent, to free from obstructions obstacles, impediments, to exhaust, to free from contact, to pass without entanglement or collision, to pass clear of, to adjust accounts, claims, differences with, to set free from debt, or pecuniary embarrassment, to come into order from confusion; to judge - to sit in judgement upon, to try, or pronounce sentence upon a person in a court of justice, to sentence, condemn, to try a cause, to determine, decide a question, to decree, order, to adjudge, to administer (law) as a judge, to form an opinion about, to estimate, to appraise, to come to a conclusion, to commit oneself to, to submit oneself to the judgement of, to arrive at a notion, to make up one's mind as to the truth of a matter, to make a mental assertion or statement.

In addition to the abovementioned meanings, the verb to clear forms phrases that allow to deeper disclose its semantics: to clear the air - to free from clouds, mists, or obscuring elements; to clear away - to remove, leave the place, so as to clear; to clear off - to remove (an encumbrance) so as to leave a thing clear; to get rid of (a debt or claim) by settling it. The semantic unity of a word lies not only in the presence of the common meaning - the significant, which subordinates separate meanings, but also in connecting these separate meanings with each other and their attachment to the same word. Hence, the nature and specificity of its polysemantic structure indicate that the use of the word in various phrases neither destroys its semantic unity nor the identity of the sound form, but reveals additional semantic shades of the word meaning.

The verbs to divide, to match and to void have their common quantitative (32 meanings) and also qualitative characteristics. The explicit indication of conflict actions, collision of opposite interests, thoughts, views, serious divergences, a sharp controversy, complications in international relations, which may lead to armed conflict actions are present in the lexical meanings of the given language units: to divide - to split up, to break or cut asunder, to penetrate by motion through, to separate, to distinguish the kinds of, to classify, to cut off, sunder, part, to establish 
or constitute a boundary between, to cause to disagree, set at variance, produce dissension in or among, to distract or perplex (a person) by conflicting thoughts or feelings, to deal out, dispense, to allocate, to direct to different things, to part into two groups; to match - to meet in combat, to fight with, to array or place in opposition or conflict with, to "pit" (a person or thing) against another, to place in competition; to void - to clear of occupants, to empty of smth., to exhaust a subject by discussion, to deprive smth. of legal validity, to make legally void or invalid, to annul or cancel, to deprive of efficacy, force or value, to set aside or nullify, to cause to compel to go away from or leave a place, to dismiss, to expel, to remove from a position, to retire, to withdraw from, to clear away by destruction or demolition, to escape from, to give up.

Our approach to semantic analysis of the English verbs denoting conflict actions allowed us to consider the meaning of the word as a complex dismembered phenomenon. As a result, the analysis itself acquires a specific focus on the study of the meaning peculiarities. Particularly interesting in this respect are the facts, when within the same word there are meanings that have nothing in common with each other or appear to be diametrically opposed in comparison with their original meaning. For instance, the verb to match contains in its semantics completely opposite emotional connotations: fight, combat, opposition, hostility, lack of unity, coherence of action, ideas and what brings happiness, calmness, agreement, collaboration, union, comparison, equality, etc. (to join in marriage, to become connected by marriage with, to associate, to join in companionship or co-operation (persons or things), to make an agreement with, to compare in respect of similarity, to examine the likeness or difference of, to regard, treat, or speak of as equal, to be equal to, to resemble sufficiently to be suitably coupled with, to correspond to, to be the "match" or counterpart of, to be mutually equal, be suitable to, to procure as a match, etc.).

The lexeme to cross (31 meanings) is characterized by its individual semantics denoting counteraction, opposition, obstacle, annulment, unfair play against someone or something, intersection, crossing, etc.: to crucify, to cancel, to erase, to strike out, to thwart, oppose, go counter to, to contradict, traverse, to cheat or double-cross, to act dishonestly in or towards, to die, to make the sign of the cross upon or over, to mark with a cross, to draw a line across, to intersect, to pass over a line, to meet and pass, to meet or face in one's way, to encounter, to breed together.

The words to top, to spill, to refuse and to prevent have 30 meanings and are characterized by both common and distinctive features. Among the common features of the lexical units to top and to spill are an indication of fray, violent confrontation or struggle, especially between large organized armed forces, situation of intense competitive activity, activities aimed at destroying / killing / overcoming someone or something, competition, destruction and others: to fight, struggle, strive, to deprive of the top, to cut off, poll, to practise cheating or trickery, to impose upon, to foist, fob off, to insult, to oppose (to top), to destroy by depriving of life, to put (or bring) to death, to slay or kill, to cause death or slaughter, to put an end to life, to 
ruin, to overthrow a person, to bring to ruin or misery, to spoil morally, to wreck, to devastate, to violate, to deprive of chastity, to employ or expend wastefully, to waste, to perish, to scatter, to empty (to spill). The lexeme to top, in its turn, appears to be semantically close to the language unit to prevent - in the meaning of 'to outdo, surpass, excel in smth.', whereas to spill and to refuse denote a rejection, refusal, denial, giving up a position, a relationship with the opposite sex, proposals, opinions, thoughts, ideas, statements, etc. (to decline (smth.), to do smth., to reject the offer of, to decline to accept or submit to a certain position, or to some relationship with oneself, to decline to meet (an opponent)). Among the distinctive semantic features, we point out the following: for to top - to put a top on, to form a top to, to furnish with a top, to cover, to exceed in height, to overtop, to rise above, to surmount, to reach the top of, ascend to the top of, to be at the top of, to have the supremacy over, to get the better of; for to refuse - to abandon, leave, depart from, to cast off, to divorce, to cease, desert, to let go, dismiss, get rid of, to prohibit or keep back from smth., to withhold permission, to resist further driving. At the same time, the verb to prevent reveals its specific, individual meanings which characterize everyday actions and processes of human activity. Some of them are related to the manifestation of contradictions, conflicts, collision, confrontation, opposition, etc.: to act before, in anticipation of, or in preparation for a future event, to meet with welcome or succour; to meet with hostility or opposition, to confront, to forestall, or baffle by previous or precautionary measures, to cut off beforehand, to debar, preclude, to stop, hinder, keep, to frustrate, defeat, bring to nought, render void or nugatory, to take possession of, to preoccupy, prejudice (a person's mind).

In general, semantics of the language units denoting conflict actions in English is marked by a precise negative orientation which is a general characteristic of the verbs denoting conflict actions.

The semantic specificity of the language units with the middle degree of polysemy to oppose, to push, to sue, to oppress, to beat, to deal, to determine, to split, to wrestle, to clear, to judge, to divide, to much, to void, to cross, to top, to spill, to refuse and to prevent lies in the fact that in addition to their specific meanings, they have their common features based on association of physical impact, collision, struggle, contradiction, proximity, connection, comparison etc.

Conclusions. Lexico-semantic analysis of the verbs with the middle degree of polysemy denoting conflict actions in modern English has shown that each lexical unit is characterized, on the one hand, by its autonomy, in the language system and, on the other - by its certain relation with other units within the semantic field. Since the structure of the language units denoting conflict actions in English consists of a large number of meanings, they may belong to many conceptual microsystems, owing to their qualitative and quantitative characteristics. As a result, various relationships between language units are established - intersection, coincidence, direct and indirect relations, etc. These changes in the semantic relations between the lexemes under study serve as a logical process for the formation of the lexis denoting conflict actions based on various transformations. 
The perspectives of further research lie in the study of semantic peculiarities of the language units denoting conflict actions in English in their interactions with the corresponding ones in both distantly related and non-related languages.

\section{REFERENCES}

1. Andreichuk N. I., Babeliuk O. A. Contrastive lexicology of English and Ukrainian languages: theory and practice : textbook. Kherson : Publishing House "Helvetica", 2019. 236 p.

2. Іваненко Н. В. Системно-структурна організація лексико-семантичного поля добро в українській та англійській мовах. Науковий вісник Херсонського державного університету. Серія “Лінгвістика". Херсон : ХДУ, 2007. Вип. 5. С. 60-64.

3. Фабіан М. П. Етикетна лексика в українській, англійській та угорській мовах. Ужгород : Інформаційно-видавниче агентство «IBA», 1998. 256 с.

4. Фабіан М. П. Семантика мовного етикету : новий підхід до ії вивчення. Сучасні дослідження з іноземної філології. Ужгород, 2014. Вип. 12. С. $7-13$.

5. Fabian M. Interdisciplinary approach to cross-language and cross-cultural communication studies. Сучасні дослідження 3 іноземної філологіï. Ужгород : ДВНЗ «УжНУ», 2019. Вип. 17. С. 9-16.

6. Simpson, John, Edmund Weiner, ed. Oxford English Dictionary. Vol. 1-20. Canada : Oxford UP, 1989.

7. Soroka T. Methodology of contrastive typological investigation of the Ukrainian, English and French axionomens. Теоретичні ци прикладні проблеми сучасної філології. Слов'янськ, 2019. Вип. 9, ч. І. С. 56-62. 